\title{
Perkembangan Perpustakaan dalam Pemenuhan Kebutuhan Informasi Masyarakat
}

\section{Anna Nurhayati}

SD Muhammadiyah Sapen Yogyakarta

annanurhayatisapen@gmail.com

\begin{abstract}
Abstrak
Kemudahan akses informasi masyarakat saat ini memaksa perpustakaan untuk mengembangkan inovasi layanan. Hadirnya beragam jenis perpustakaan menjadi salah satu dampak kemudahan akses informasi. Perpustakaan konvensional kini bermetamorfosis menjadi perpustakaan digital bahkan bookless library. Perubahan fisik perpustakaan ini menjadi bukti bahwa perpustakaan senantiasa berkembang dalam memenuhi kebutuhan penggunanya. Perpustakaan hibrida menjadi salah satu jenis bentuk yang saat ini banyak diimplementasikan di berbagai perpustakaan. Perpustakaan hibrida menjadi penyeimbang kebutuhan masyarakat yang memanfaatkan koleksi cetak dan koleksi digital. Akselerasi layanan perpustakaan tidak sekedar pada layanan fisik, namun juga pada layanan yang mendorong masyarakat untuk berpikir dan berprilaku intelektual.
\end{abstract}

\author{
Kata kunci: \\ perpustakaan konvensonal \\ perpustakaan digital \\ bookless library
}

\section{Pendahuluan}

Keberadaan perpustakaan di tengah kehidupan tentu akan membawa dampak pada perubahan kehidupan masyarakat. Berbagai jenis perpustakaan berperan dalam rangka peningkatan kapasitas individu dan masyarakat. Perpustakaan sebagai pusat pengetahuan terseleksi, dengan perkembangan sumber daya teknologi dan akses terhadap berbagai sumber informasi di era pengetahuan, telah memberi penekanan pada kesadaran individu menjadi pembelajar seumur hidup.

Ledakan informasi berdampak pada sulitnya memberikan informasi yang benar kepada masyarakat. Peralatan teknologi informasi seperti, komputer, gadget, laptop, I-pad bukan benda asing bagi masyarakat. Kebutuhan informasi dapat dengan mudah diakses kapanpun dan dimanapun dari sumber informasi digital di tangan mereka.

Hadirnya media informasi dan komunikasi dewasa ini berdampak pada prilaku masyarakat di berbagai bidang. Terlepas dari dampak negatif, masyarakat terdorong menjadi individu pembelajar untuk melahirkan inovasi yang bermanfaat. Inovasi di bidang ekonomi berbasis teknologi komunikasi yang telah hadir di tengah-tengah masyarakatantara lain, inovasi layanan jasa transportasi online, hingga kemudahan layanan belanja online menjadi hal yang biasa bagi masyarakat di masa kini. Hal ini menjadi bukti pesatnya penggunaan media informasi dan komunikasi dalam kehidupan. Berdasarkan data statistik hasil survey Asosiasi Penyedia Jasa Internet Indonesia (APJII) tahun 2017, bahwa pertumbuhan penggunaan internet saat ini mencapai 143,26 juta (54,68\%) dari 262 juta jiwa jumlah penduduk Indonesia. Angka ini meningkat dari survey dua tahun sebelumnya yaitu 132,7 juta jiwa. Jika dilihat dari komposisi pengguna berdasar usia 49,52\% adalah mereka yang memasuki usia produktif. Sedangkan perangkat yang dipakai untuk akses paling banyak adalah smartphone yang mencapai 44\% dari total pengguna internet, dengan rata-rata tertinggi durasi pemakian 1-3 jam perhari. Sedangkan layanan internet yang dimanfaatkan adalah gaya hidup seperti chat dan media sosial menempati urutan tertinggi mencapai $89,35 \%$. 
Berdasarkan data di atas, bahwa kemudahan mendapat informasi dan komunikasi begitu mudah. Dengan sekali sentuh menggunakan smartphone informasi bisa didapatkan sesuai keinginan bahkan melebihi harapan. Namun sayangnya, dari seperempat hari mereka gunakan untuk pemenuhan gaya hidup yaitu berinteraksi dengan chat.

Lancaster, dalam Wulandari (2011) menyatakan, seorang pustakawan dan pengajar di bidang ilmu perpustakaan di Amerika memperkirakan, dampak kehadiran teknologi informasi dan komunikasi akan mengubah kehidupan manusia, yang disebut dengan masa "paperless society" atau masyarakat tanpa kertas, serta akan hadir jaringan berbasis sistem komunikasi yang memiliki banyak karakteristik yang saat ini terjawab dengan teknologi berbasis internet.

Perjalanan perpustakaan dalam memenuhi kebutuhan pemustaka berdampak pada pengelompokan tipologi perpustakaan. Berbagai jenis perpustakaan memiliki karakteristik yang berbeda-beda. Dilihat dari sisi sejarah perkembangannya, semua perpustakaan memiliki kesamaan untuk memenuhi kebutuhan. Artikel ini akan membahas perkembangan jenis perpustakaan dalam memenuhi kebutuhan penggunanya.

\section{Pemenuhan Kebutuhan Informasi di Perpustakaan}

Pemenuhan kebutuhan informasi masyarakat bergantung dengan proses distribusi informasi. Sumber informasi dapat terdistribusi melalui melalui lembaga formal dan non formal. Gambar 1 mengilustrasikan pergerakan dari struktur kelembagaan berbasis lokasi atau lembaga hingga sumber daya terdistribusi.

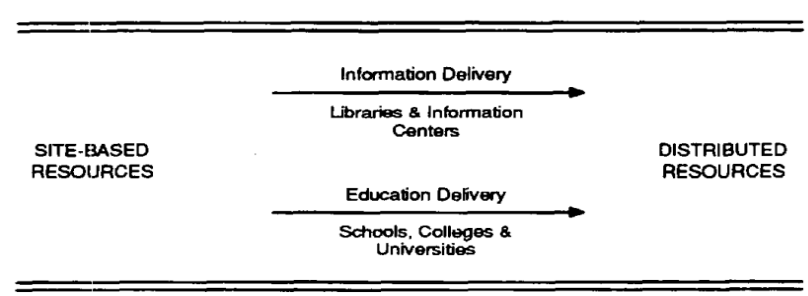

Gambar 1 Site-Based to Distributed Resources,Sutton (1996: 27)

Perpustakaan berperan sebagai institusi dalam transformasi sosial masyarakat. Perpustakaan merupakan insfrastruktur sosial yang tidak dapat dipisahkan dari masyarakat dan kekuatan yang mendukung menyatukan budaya masyarakat, karena lingkungan perpustakaan membawa dampak perubahan di masyarakat.

Dalam memenuhi kebutuhan informasi, David Reith dalam Juchnevič (2014), membedakan fungsi perpustakaan antara lain; (1) sebagai repository, peran penyimpanan dan pengelolaan dokumen masyarakat dengan cara memperoleh (mengumpulkan), melestarikan, mendiskripsikan dokumen yang diciptakan manusia; (2) distribusi kumpulan data (informasi); (3) peran pendidikan, menghubungkan fungsi pembelajaran formal dan informal, pengorganisasian pengajaran dengan memberikan informasi terbaru dan berguna untuk merangsang orang untuk belajar seumur hidup; (4) peran sosial avokasi, peran ini seperti penyebaran sumber daya perpustakaan, berkaitan dengan tugas dokumentasi perpustakaan, layanan efektif terhadap kegiatan sosial dan budaya; (5) pusat kebudayaaan, dimana peran ini mendukung penyebaran budaya masyarakat setempat, inspirasi masyarakat untuk berpartisipasi di lingkungan lokal; (6) layanan informasi umum dan khusus yang mendukung kegiatan ekonomi lokal dan pemerintah, pelaksanaan penelitian dan pendidikan; (7) tempat perlindungan, artinya berperan bagi ruang publik, dimana kelompok rentan sosial seperti keluarga bermasalah, tuna wisma dapat memanfaatkan tempat ini.

Ketujuh fungsi yang dikemukakan oleh David Reith di atas tampak, dalam pemenuhan kebutuhan 


\section{A. Nurhayati}

informasi masyarakat, perpustakaan tidak sekedar penyedia informasi saja. Peran sebagai agen informasi yang bersifat transformasional nantinya membawa nilai-nilai perubahan di masyarakat.

\section{Perpustakaan dan Informasi}

Sebelum mendalami hubungan perpustakaan dan informasi, terlebih dahulu melihat makna informasi. Menurut Madden(2000), informasi dibedakan menjadi empat hal : Pertama informasi sebagai representasi dari pengetahuan, informasi adalah pengetahuan yang tersimpan. Secara tradisional media penyimpanannya adalah buku dan media elektronik. Kedua, informasi sebagai data di lingkungan. Informasi dapat diperoleh dari serangkaian rangsangan dan fenomena lingkungan. Ketiga, informasi sebagai bagian dari proses komunikasi. Artinya fokus pada orang sebagai penyampai bukan dalam kata atau data. Waktu dan faktor sosial memainkan peran penting dalam pengolahan dan interpretasi informasi. Keempat, informasi sebagai sumber atau komoditas dimana informasi ditransmisikan dalam pesan dari pengirim ke penerima. Penerima menginterpretasikan pesan sebagaimana dimaksud oleh pengirim.

Buckland (1991: 355), menggaris bawahi bahwa, sebuah informasi didapatkan seseorang dari berbagai macam sumber, obyek dan kejadian nyata yang vatiatif, artinya seseorang dalam mendapatkan informasi dari proses kesengajaan. Namun, tidak mudah membuat seseorang menerima informasi, karena sangat tergantung pada kebutuhannya.

Merujuk pada pengertian informasi sebagai sesuatu (informatioan as think), informasi berujud data dokumen yang memiliki nilai. Informasi dalam konteks berupa koleksi buku, manuskrip bahkan artefak menjadi hasil akumulasi pemikiran manusia. Tugas lembaga informasi seperti perpustakaan untuk mengatur sesuai dengan metode atau standar organisasi informasi, sehingga dapat diakses publik dengan mudah.

Teknologi informasi dan komunikasi yang hadir ditengah masyarakat memberikan kemudahan akses seseorang untuk memenuhi kebutuhan informasi. Diawalai dengan hadirnya media komunikasi dengan telepon genggam dilanjutkan hadirnya internet hingga yang saat ini dapat kita rasakan, membius manusia dalam kebebasan akses informasi. Tuntutan keinginan masyarakat akan kebutuhan informasi seperti upaya membangun situs koleksi digital membawa dampak lahirnya lembaga informasi yang tidak dapat berdiri sendiri. Lembaga informasi dalam hal ini adalah perpustakaan memiliki peran sebagai gete resource antara masyarakat dan informasi sebagai ilmu pengetahuan.

\subsection{Perpustakaan sebagai Katalisator}

Perpustakaan secara fisik, memadukan antara masa lalu (koleksi cetak) dan sekarang (teknologi informasi baru). Untuk memaksimalkan potensinya dalam menambahkan nilai fungsi institusi sesuai dengan misi, harus dilihat dengan perspektif dan pemahaman baru. Integrasi teknologi informasi sebaiknya benar-benar diberdayakan menjadi katalisator yang mengubah perpustakaan menjadi pusat intelektual kehidupan yang lebih penting dan kritis di masyarakat.

Ketika mulai mengkonsep dan merencanakan perpustakaan untuk masa depan, pertanyaan analisis yang diajukan adalah, jika pemustaka sekarang dapat memperoleh informasi dalam beragam format dan dapat mengakses di manapun, mengapa perpustakaan, sebagai fisik memainkan peran penting dalam pembaharuan dan kemajuan kehidupan intelektual institusi? Perpustakaanadalah satu-satunya lokasi terpusat dimana teknologi informasi baru dan yang baru muncul dapat dikombinasikan dengan sumber pengetahuan konvensional di lingkungan yang berfokus pada pengguna dan layanan yang mendukung pola pembelajaran, pengajaran, dan penelitian sosial saat ini. Internet cenderung mengisolasi orang. Dengan demikian, perpustakaan sebagai tempat fisik, telah 
melakukan hal yang sebaliknya yaitu, menjadi institusi sumber belajar yang dinamis, perpustakaan dapat menjadi inti untuk membangun komunitas intelektual dan kegiatan ilmiah

\subsection{Perpustakaan sebagai Laboratorium Pembelajaran}

Freeman, dkk.,(2005) menjelaskan seiring dengan penciptaan teknologi baru, institusi perpustakaan mempertimbangkan masa depan peranya. Artinnya peran tersebut tidak hanya melihat kebutuhan saat ini saja dikalangan akademisi, tetapi seluruh lapisan masyarakat. Tantangan bagi institusi perpustakaan dalam merancangan suasana lingkungan belajar, penelitian guna mendukung evolusi yaitu menanggapi permintaan pemustaka. Di Perpustakaan sekolah, masing-masing institusi mengembangkan visi untuk fasilitas mereka berdasarkan analisis menyeluruh. Teknologi akan mempermudah layanan khususnya akses informasi yang digunakan tanpa mengenal ruang dan waktu untuk melakukan pekerjaan akademik mereka.

Penggunaan data base elektronik, format digital, dan media interaktif juga telah mendorong perubahan besar dari dominasi belajar mandiri menjadi lebih kolaboratif dan interaktif. Seorang siswa bisa pergi ke perpustakaan sebagai perpanjangan logis dan ilmiah selama kelas. Perpustakaan adalah tempat untuk akses dan penjelajahan bersama siswa lain. Beragam bentuk informasi mereka dapatkan, analisa informasi dalam diskusi kelompok, dan menghasilkan publikasi atau presentasi untuk kemudian disampaikan pada di depan kelas mereka.

\section{Jenis Perpustakaan}

\subsection{Perpustakaan Konvensional}

Menurut Leeder (2013), Perpustakaan konvensioal sering disebut dengan perpustakaan tradisional. Banyak perdebatan tentang definisi perpustakaan konvensional ini. Menanggapi perdebatan yang dimulai pada Konferensi Nasional ACRL 2013, Kim Leeder menyajikan hasil survei literatur yang membahas penggunaan retoris dan makna ungkapan tersebut. Hasil menunjukkan bahwa "perpustakaan tradisional" biasanya didefinisikan sebagai ruang fisik yang menekankan koleksi fisik, dan sering disebut sebagai tandingan ke perpustakaan "modern" atau "digital".

Menurut Reddy, dkk (1999) Perpustakaan tradisional ditandai sebagai berikut:

1). Penekanan pada penyimpanan dan pelestarian barang fisik, terutama buku dan majalah

2). Membuat katalog pada tingkat tinggi dan bukan satu detail, misalnya, penulis dan indeks subjek yang bertentangan dengan teks lengkap

3). Browsing berdasarkan kedekatan fisik bahan terkait, misalnya, buku tentang sosiologi saling berdekatan satu sama lain di rak.

4). Bersifat pasif, informasi dususun secara fisik di satu tempat; pengguna harus pergi ke perpustakaan untuk mempelajari apa yang ada dan memanfaatkannya.

L.A. Ogunsola (2011), perpustakaan adalah koleksi buku, manuskrip, jurnal, dan sumber informasi lain yang tercatat. Di perpustakaan tradisional, katalog digunakan untuk menemukan bahan pustaka tradisional. Pernyataan ini hanya menggaris bawahi keteguhan istilah "tradisional" dan erat hubungannya dengan dunia fisik.

Sutton (1996), menyebutkan perpustakaan tradisonal sebagai tipe perpustakaan murni, dapat didefinisikan sebagai tempat khusus dengan koleksi terbatas, informasi bersifat entitas primer seperti buku dan jurnal dan media alternatif seperti bentuk mikro dari segala jenis, gambar, film, dan rekaman. Selain itu, ini berisi berbagai cetak sekunder atau meta-informasi dalam bentuk katalog kartu, berbagai tesaurus, dan alat pencarian lainnya yang merujuk pada konten utama perpustakaan.

Semua mekanisme akses interface perpustakaan konvensional dibatasi secara geografis atau 


\section{A. Nurhayati}

tempat. Dengan kata lain, pengguna harus datang ke perpustakaan untuk mengakses informasi aktual atau meta-nya. Secara umum, di mana intermediasi diperlukan antara pengguna dan informasi, disediakan oleh pustakawan, dan peran ini biasanya. dilakukan oleh pustakawan referensi. Oleh sebab itu Sutton (1996), dalam konteks ini pustakawan memiliki (setidaknya) sifat berikut:

1). Pengetahuan tentang lingkup koleksi objek informasi

2). Pengetahuan tentang proses yang diperlukan untuk memperoleh kebutuhan pengguna;

3). Pengetahuan tentang berbagai bentuk meta-informasi di perpustakaan;

4). Pengetahuan tentang proses yang diperlukan untuk memetakan kebutuhan pengguna terhadap permintaan pengganti (query) atau informasi alternatif, berdasarkan informasi meta-informasi yang ada di perpustakaan.

Atkinson (1993), memperjelas tanggung jawab penting layanan informasi harus membantu pengguna dalam menentukan informasi apa yang mereka butuhkan untuk melakukan pekerjaan mereka. Tanpa bantuan ini, waktu yang dibutuhkan pengguna untuk menemukan informasi menjadi meluas dan tidak efektif. Kegiatan layanan informasi memberikan bantuan dengan bertindak berbasis informasi dengan memilih, membedakan, merujuk, dan mengutamakan unit informasi, untuk meningkatkan kemampuan pengguna untuk menemukan unit informasi tersebut dan menentukan unit mana yang layak untuk diambil dan diserap.

Kekuatan layanan perpustakaan konvensional adalah menyediakan layanan mediasi dan membantu pengguna dalam pengumpulan informasi dibutuhkan di dalam gedung perpustakaan. Oleh karena itu bantuan yang dibutuhkan pengguna untuk memanfaatkan sumber daya ini sepenuhnya harus diberikan dengan tepat hingga koleksi cetak ditemukan.
Pertumbuhan layanan informasi jaringan elektronik kepada pengguna akhirnya menghapus model penyampaian layanan perpustakaan ini. Jika konten inti yang dibutuhkan pemustaka beralih ke jaringan, tentu ketermanfaatan meja referensi tradisional akan hampir mati, karena informasi pengguna digunakan untuk bermigrasi dari koleksi cetak dan ke web. Pergeseran dari perpustakaan tradisional ke hibrida bahkan digital bukan hanya evolusi teknologi, namun memerlukan perubahan paradigma dimana orang mengakses dan berinteraksi dengan informasi.

\subsection{Perpustakaan Hibrida}

Konsep perpustakaan sebagai tempat fisik dimana seseorang mengunjungi akses informasi berubah secara dramatis ke tempat-tempat virtual tanpa dinding tapi menyediakan akses terorganisir ke catatan intelektual ini berarti bahwa perpustakaan menyediakan informasi dimanapun berada, baik di tempat fisik maupun di ruang informasi digital. Kondisi ini membuka jalan bagi layanan perpustakaan model hibrida. Informasi tersedia dalam jumlah besar yang di seluruh dunia, mengakibatkan media cetak tidak lagi dianggap cukup dalam penyimpanan karena volume akses informasi yang terus meningkat.

Peran dasar perpustakaan adalah memilih, mengakuisisi, memproses, menyimpan dan menyebarkan sumber informasi kepada pengguna. Tetapi pada era informasi sekarang (yaitu era ICT), perpustakaan bersaing dengan segala cara yang ada untuk memenuhi kebutuhan informasi para pengguna yang beragam, mengingat format cetak dan elektronik, sehingga mengarah ke masa kini, yang selalu dibutuhkan, pengembangan perpustakaan hibrida

Garrod, dkk., (1998), istilah "hibrida" sering digunakan dalam mendiskripsikan aktivitas atau layanan yang menggabungkan dua fitur mapan. Misalnya istilah "manajer hibrida" yang sedang pada tahun 1970an dan 1980 an, untuk para manajer di 
perusahaan IT mengkombinasikan pengetahuan IT dengan pemahaman tentang personil dan permasalahan manusia lainnya. Di dunia perpustakaan sebaiknya perlu adanya profesional perpustakaan hibrida yang menggabungkan keterampilan perpustakaan dan informasi dengan kemampuan komputasi teknis.

Perpustakaan hibrida" istilah pertama kali diciptakan oleh Chris Rusbridge pada tahun 1998 di Sebuah artikel untuk Majalah D-Lib. Perpustakaan hibrida adalah istilah baru dan baru yang muncul untuk perpustakaan umum dan akademis karena dengan layanan dan koleksi yang ada, mereka dapat dengan mudah menyediakan layanan elektronik atau layanan online dan dengan mudah membangun koleksi digital. Perpustakaan hibrida berkembang dalam 1990an dengan kemunculannya

Perpustakaan hibrida secara sederhana dapat diartikan sebagai tuntutan pengintegrasian perpustakaan tradisional dengan perpustakaan digital. Selama ini perpustakaan digital berfungsi sebagai tambahan bukan sebagi pengganti perpustakaan konvensional. Pengguna informasi kontemporer sekarang harus beropersi di lingkungan hibrida dimana sumber berbasis kertas dan elektronik digunakan satu sama lain.

Pedapat Sutton (1996), semakin memperjelas devinisi dari perpustakaan hibrida. Untuk menyimpulkan perpustakaan hibrida Sutton melihat dari sisi layanan dalam perjalanan mulai layanan tradisional hingga digital. Perpustakaan tradisional didefinisikan tempat khusus pengumpula informasi yang terbatas baik dari sisi fisik maupun geografis. Sedangkan perpustakaan otomasi layanan menggunakan system komputerisasi serial control, sirkulasi dan katalogisasi, dengan fitur utama adalah akses public secara online (OPAC). Perpustakaan ini menjadi alat mengarah pada media non digital dan fokusnya pada koleksi lokal. Sedangkan pada perpustakaan digital, tempat atau lokasi akan ditinggalkan. Untuk menjembantani perbedaan layanan kedua perpustakaan ini hadirlah perpustakaan hibrida yang mengintegrasikan layanan perpustakaan tradisonal dan digital.

Di perpustakaan hibrida menggambarkan keseimbangan dari meta informasi dan informasi cetak semakin mendekati digital. Namun, karakteristik yang benar-benar membedakan antara perpustakaan otomatis dan perpustakaan hibrida adalah: koeksistensi informasi primer digital dan non digital. Selain itu untuk pertama kalinya, kemungkinan untuk akses yang tidak dibatasai secara geografis, baik untuk beberapa subset dari koleksi digital perpustakaan atau sumber digital yang berada di tempat lain dimana perpustakaan menyediakan jaringan gateway.

Perpustakaan hibrida lebih dari sekedar interface, namun menawarkan penemuan sumber daya yang terintegrasi dalam berbagai format, baik analog atau digital, secara lokal, nasional atau internasional. Perpustakaan hibrida dipandang sebagai tempat dengan layanan fisik dan virtual yang mendukung aktivitas pengguna.

Pengetahuan dan informasi adalah fenomena multi dimensi dan yang telah berkembang pada perkembangan geometris. Pertumbuhan ini sebenarnya mengharuskan kebutuhan akan pemilihan informasi yang tepat oleh pustakawan bagi penggunanya. Oleh karena itu, Okiy (2002) mengungkapkan bahwa kecenderungan penyediaan informasi saat ini di perpustakaan saat ini paling baik dilakukan melalui penerapan teknologi informasi dan komunikasi (TIK) yang membantu dalam penyediaan dan perluasan cakupan informasi bagi pelanggan perpustakaan, terlepas dari lokalitasnya.

Perpustakaan hibrida menyediakan akses informasi digitalyang efisien dan hemat biaya. Dalam sejarah pengembangan perpustakaan ini harus menunggu kemajuan di bidang telekomunikasi dan penyimpanan digital massal yang terdistribusi secara geografis. Sejak pertengehan 1980an, 


\section{A. Nurhayati}

dengan peningkatan bandwidth dari megabyte, lalu gigabyte, terabyt hingga pentabyt, digital informasi menjadi lebih hemat biaya, daripada penyimpanan menggunakan kertas. Seiring tren teknologi kita akan melihat peningkatan jumlah informasi di perpustakaan hibrida yang ditinggalkan. Pergeseran terjadi pada penyimpanan kertas yang berfungsi interface untuk informasi yang bersifat permintaan.

Sutton (1996:137), tingkat intermediasi manusia ini menjadi pergeseran mendasar. Model pemberian layanan sumber daya di perpustakaan konvensional lebih sederhana, sedangkan perpustakaan otomasi mengarah pada model konsultasi. Selain itu pustakawan terlibat aktif dalam proses akses dan penilaian informasi langsung. Banyak perpustakaan khusus dan beberapa perpustakaan umum, proses konsultatif ini lebih dari sekedar akses dan penilaian untuk melakukan sintesis dan penyiapan produk informasi. Layanan konsultatif ini dirancang untuk memenuhi kebutuhan informasi spesifik pemustaka, seperti: informasi yang benar, berdasarkan sumber dan waktu tepat, dalam bentuk yang benar dan di tempat yang tepat.

Melihat bentuk layanan yang diberikan, peran pustakawan tentu juga akan mengalami pergeseran. Pustakawan dituntut lebih memiliki keahlian dalam memanfaatkan teknologi elektronik. Pekerjaan yang biasa dilakukan diatas meja referensi kini bergeser menjadi pakar informasi menggunakan teknologi karena sumber informasi seperti internet dan media elektronik menjadi lebih penting.

Allen (2005), sejauh kompetensi teknis, pengetahuan dan atau keterampilan dalam teknologi berikut diperlukan oleh pustakawan antara lain; sistem manajemen informasi, perangkat lunak open source, desain web (termasuk XML dan Java Script), aplikasi multimedia, karena pengguna semakin mengandalkan koleksi dan layanan yang diakses melalui web.

\subsection{Perpustakaan Digital}

Istilah yang digunakan untuk perpustakaan digital (digital library) sering dipertukarkan dengan perpustakaan elektronik (e-library), dan perpustakaan maya (virtual library).

Ashikuzzaman (2016), ketika perpustakaan otomatis masuk ke LAN (Local Area Networking) dan jaringan CD-ROM dan mulai menyediakan e-journal dan jenis publikasi lainnya, maka perpustakaan tersebut dikenal sebagai perpustakaan elektronik. Sumber daya perpustakaan elektronik ada dalam bentuk cetak dan elektronik. Media elektronik digunakan untuk penyimpanan, pengambilan dan penyampaian informasi.

Ashikuzzaman lebih jauh menjelaskan bahwa virtual library adalah istilah pendamping untuk perpustakaan digital, yang dibawa oleh National Science Foundation. Konsep virtual library juga muncul bersamaan dengan perpustakaan elektronik dan perpustakaan digital. Kemunculan ini barangkali karena semua penggunaan informasi melalui jaringan di desktop yang cukup praktis tanpa adanya fisik buku di rak. Perpustakaan virtual dapat didefinisikan secara sederhana sebagai perpustakaan digital berbasis internet atau perpustakaan tanpa dinding. Konsep perpustakaan virtual adalah bahwa setiap orang yang memiliki komputer dan koneksi ke jaringan perpustakaan dapat mengakses, tidak hanya sumber daya perpustakaan itu, namun juga beragam informasi yang tersedia melalui jaringan nasional dan internasional seperti internet dan intranet tanpa hadir secara fisik di perpustakaan.

Siri (2003) menyebutkan, Federasi Perpustakaan Digital mendefinisikan perpustakaan digital sebagai organisasi yang menyediakan sumber daya, termasuk staf khusus, untuk memilih, menyusun, menawarkan akses intelektual untuk, menafsirkan, mendistribusikan, menjaga integritas, dan memastikan kondisi dari waktu ke waktu koleksi karya digital, sehingga dapat dimanfaatkan.

Perpustakaan digital adalah perpustakaan tempat koleksi disimpan dalam format digital 
(berlawanan dengan media cetak, microform, atau media lainnya) dan dapat diakses oleh komputer selain itu konten dapat disimpan secara lokal, atau diakses dari jarak jauh.

Dari penjelasan diatas perpustakaan digital mengarahkan kepada kita bahwa organisasi yang menyediakan akses dan koleksi digital kepada pengguna tidak terbatas ruang dan waktu. Penyediaan akses juga diperkuat dengan insfrastruktur yang memadai dan mendukug keberlangsungan pemenuhan kebutuhan informasi ternasuk didalamnya sumber daya manusia yang memiliki kompetensi.

Menurut Subrata (2009), kebutuhan dalam perpustakaan digital adalah perangkat keras, perangkat lunak, dan jaringan komputer sebagai elemen-elemen penting infrastruktur sebuah perpustakaan digital. Namun, perangkat utama yang diperlukan dalam perpustakaan digital adalah komputer personal (PC), internet (inter-networking), dan world wide web (www). Ketiga hal tersebut memungkinkan adanya perpustakaan digital.

Sreenivasulu (2000) menerangkan, pada lingkungan digital, pustakawan dan ilmuwan informasi diperlukan untuk mengemas dan mengemas ulang informasi, untuk penerbitan elektronik. Hal ini dilakukan untuk tujuan referensi, memberi tahu pengguna tentang strategi mengidentifikasi sumber elektronik yang relevan.

Setiap orang yang memiliki akses ke jaringan perpustakaan digital, dapat menjadi penerbit hanya dengan memposting pesan ke grup diskusi online. Lingkungan virtual benar-benar terbuka untuk semua. Dalam beberapa kasus, pustakawan memiliki kesempatan untuk mendigitalkan materi menarik dalam koleksi perpustakaan mereka, untuk kemudian dapat diakses oleh pengguna website secara luas.

\subsection{Bookless Library}

Setelah pembahasan perpustakan digital kini telah hadir perpustakaan tanpa buku (bookless library). Belum banyak pembahasan yang mendefinisikan tentang perpustakaan ini. Husna (2012) menjelaskan, sama halnya dengan jenis perpustakaan umum, akademis dan sekolah, hanya saja secara fisik bookless library yang tidak memiliki buku cetak. Perpustakaan ini menawarkan koleksi digital berupa karya sastra, bahan bacaan dan bahan penelitian ilmiah dan akademis. Bookless library adalah perpustakaan yang awalnya adalah perpustakaan konvensional, sehingga dapat menggunakan ruang pernah digunakan untuk menempatkan buku-buku cetak. Ruangan itu diganti dengan perangkat komputer umum, e-reader dan teknologi lain yang digunakan untuk mengkonsumsi dan memproduksi media digital.

$\mathrm{Hal}$ yang menjadi alasan sebuah lembaga informasi beralih pada pemanfaatan perpustakaan ini memiliki keunggulan hampir sama dengan digital library. Menurut Negi (2015), perpustakaan ini memiliki keistimewaan:

1). Tidak ada batasan fisik dan waktu; selama koneksi internet tersedia,pemustaka tidak perlu pergi langsung ke perpustakaan; orangorang diseluruh dunia dapat akses informasi yang sama, dengan waktu bersamaan selama 24 jam.

2). Akses ganda (multiple accsess), sumber daya dapat digunakan bersamaan oleh sejumlah lembaga dan pelanggan. Untuk masalah hak cipta dapat diselesaikan dengan cara pemberian hak akses kepada peminjam. Setelah masa peminjaman selesai, maka koleksi secara otomatis dikembalikan dan dapat digunakan peminjam lain.

3). Temu kembali informasi (information retrieval), pengguna dapat mencari dengan menggunakan istilah pecarian apapun (kata, frase, judul, nama, subyek) untuk menelusur setiap entri koleksi. Selain itu memberikan tampilan user friendly serta, memberikan layanan satu klik untuk setiap akses. 


\section{A. Nurhayati}

4). Pelestarian dan konservasi, digitalisasi bukanlah solusi pelestarian jangka panjang untuk koleksi fisik, namun akan mendapatkan semacam salinan, untuk bahan yang jika tidak bisa didegradasi dari penggunaan berulang-ulang.

5). Tempat (space), tidak seperti perpustakaan tradisional terbatas oleh ruang penyimpanan, perpustakaan ini memiliki potensi penyimpanan koleksi yang lebih banyak dengan ruang fisik sangat kecil.

6). Nilai tambah (added value), karakteristik obyek tertentu, peningkatan kualitas gambar.

Melihat perkembangannya, perpustakaan ini dianggap sebagai model perpustakaan yang potensial untuk dikembangkan di masa depan. Namun untuk saat ini masih mengalami tantangan yang akan menjadi kelemahan perpustakan digital bahkan bookless library terkait dengan sumber daya, aksesibilitas, permasalahan kompetensi pustakawan yang belum sesuai. Masalah hak cipta pengarang buku, tidak semua pengarang mengizinkan karyanya didigitalkan. Hal ini berhubungan dengan kebijakan tentang royalti yang belum jelas, bila karyanya didigitalkan.

\section{Analisis Perkembangan Perpustakaan}

Perpustakaan secara konvensional dianggap sebagai toko buku yang tersedia untuk kalangan tertentu. Perkembangan selanjutnya perpustakaan dianggap sebagai pusat informasi. Munculnya konsep ICT memaksa perpustakaan tradisional untuk berubah. Koleksi cetak telah yang awalnya sebagai bentuk warisan ilmu, digantikan oleh informasi untuk diseminasikan guna kepentingan perkembanganilmu pengetahuan.

Kemajuan di bidang ICT, berdampak pada permintaan pengguna disesuaikan sesuai perubahan teknologi. Untuk memenuhi permintaan pengguna seperti akuisisi menyediakan ICT, penyimpanan, pemrosesan dan penyebaran informasi dengan beragam layanan berkualitas.
Teori ilmu perpustakaan mengatakan perpustakaan merupakan suatu organisasi yang selalu mengalami pertumbuhan (growing organism). Perkembangan ilmu perpustakaan dan informasi terus berkesinambungan menjadi tempat ICT yang akan menjadikan banyak dampak pada layanan perpustakaan. Akses layanan perpustakaan konvensional yang tertutup berubah menjadi terbuka (open accsess). Perpusatakaan sistem terbuka bergerak menjadi sistem elektronik atau otomasi dan menuju perangkat eletronik.

Perpustakaan konvensional memiliki koleksi fisik yang terdapat pada media cetak, manuskrip, buku dll, yang diatur menggunakan sistem tertentu dalam proses temu kembai informasi secara manual. Koleksi perpustakaan memerlukan tindakan pelestarian seperti perawatan koleksi secara berkala. Proses temu kembali informasi dapat dilakukan dengan system manual dan menggunakan titik akses yang terbatas, sehingga koleksi tidak mudah ditemuakan atau terlacak oleh pemustaka. Dengan demikian informasi terbatas pada dinding bangunan yang dikelola oleh pustakawan yang akan menjadi pemandu dalam ruangan tersebut.

Perpustakaan hadir guna memenuhi kebutuhan pencarian informasi. Kebiasaan membaca dengan media cetak masih dilakukan oleh masyarakat, di tengah-tengah hadirnya media berteknologi yang akan mempermudah mendapatkan semua informasi untuk dibaca. Perpustakaan hibrida hadir menjadi penyeimbang antara layanan konvensional dan digital. Perpustakaan hibrida terdiri dari bahan cetak konvensional seperti buku, majalah, jurnal dan juga materi berbasis non konvensional atau elektronik seperti buku audio, jurnal elektronik, e-book, dll. Untuk memenuhi kebutuhan, layanan perpustakaan hibrida didukung dengan tenaga perpustakaan ahli dan terlatih dalam pengoperasian mesin elektronik seperti komputer, scanner dan juga dalam pencarian berbagai informasi yang tersedia di era digital. Perpustakaan ini perlahan akan 
berevolusi menjadi bentuk lain yaitu perpustakaan digital.

Perpustakaan digital merupakan kumpulan informasi digital atau elektrik yang dikelola dengan layananmodern.Informasiyang diperoleh, disimpan, diproses dengan bantuan perangkat elektronik. Untuk mengakses sumber daya di perpustakaan jenis ini, memerlukan jaringan internet. Seluruh layanan perpustakaan sepenuhnya terautomasi dan semua sumber berbentuk digital. Perpustakaan ini bersifat heterogen dan mencakup pekerjaaan yang berkaitan dengan informasi, bagaimana mendapatkanuntuk kemudian mendigitalkan, menyimpan, menemukan, menghubungkan dan berbagi informasi.

Dari beberapa penjelasan tentang jenis perpustakaan, dapat dikatakan bahwa perpustakaan hibrida dan digital memberikan layanan kebutuhan informasi terhadap masyarakat modern saat ini. Kedua perpustakaan ini dikelompkkan sebagai perpustakaan modern, sedangkan bookless library dapat dikatan sebagai perpustakaan masa depan. Perpustakaan modern memang memiliki kelebihan dalam hal penataan koleksi sumber cetak dan non cetak dengan sistematis dan teratur; berupa format digital yang mempermudah dalam pengolahan oleh komputer; akuisisi, penyimpanan, penyebarluasan dan pengambilan informasi dengan teknologi; akses seluruh pemilikan perpustakaan dapat diakses secara langsung maupun tidak langsung di seluruh jaringan dengan bantuan internet; mendukung dan menyediakan layanan akses online dan offline.

Setiap perubahan dari sebuah institusi tentu akan membawa dampak. Sama halnya dengan perpustakaan modern juga memberikan dampak atau masalah seperti serangan virus komputer dan juga bahaya radiasi dari monitor. Permasalahan lain yang muncul adalah: (1) Hak cipta; digitalisasi berakibat konten atau suber daya penulis dapat kepada orang lain tanpa sepengetahuan penulis. Meskipun terdapat kebijakan tentang hak cipta, namun era digital sangat sulit untuk menyelamatkan hak kekayaan intelektual seorang penulis atau penerbit; (2) Selanjutnya kecepatan akses, semakin banyak computer yang terhubung, otomatis server membuat website lambat; (3) Biaya awal yang cukup tinggi, perpustakaan modern membutuhkan biaya untuk software, hardware, jaringan kominikasi serta peralatan lain yang sangat mahal, khususya bagi perpustakaan yang berasal dari institusi non profit; (4) Permasalahan band width, berbagai jenis koleksi seperi multimedia membutuhkan kecepatan dalam mengunduh atau mengunggah materi digital. Jika band width tidak stabil maka proses kegiatan digital akan lambat dan menghabiskan waktu; (5) efisiensi, ledakan informasi mengakibatkan membanjirnya berbagai jenis informasi yang akan menyulitkan untuk memilah topic-topik yang benar-benar dibutuhkan; (7) lingkungan, masih banyak pengguna perpustakaan konvensional yang belum dapat atau menerima kehadiran perpustakaan modern. Kelompok ini masih menganggap bahwa membaca dalam bentuk cetak lebih mudah daripada membaca informasi di komputer.

Konsep Lancaster memprediksikan perpustakaan sebagai tempat penyimpanan koleksi fisik akan semakin usang. Perkiraan Lancaster memberikan tantangan perpustakaan untuk memperhatikan kebutuhan informasi agar tidak ditinggalkan pengguna.

Berdasarkan hasil survei APJII tahun 2017 menunjukkan, pemanfaatan teknologi informasi kebutuhan terkait dengan perilaku pencarian informasi. Pengguna akan mengenali kebutuhan informasi, mengartikulasikan menjadi pertanyaan dan akan menerima tanggapan baik tertulis, visual yang akan memuaskan kebutuhan informasi. Persyaratan informasi minimal memadai untuk mencerminkan kebutuhan penggunanya. Hal yang disayangkan, berdasar hasil survey tersebut, masyarakat cenderung menghabiskan waktu dengan smart phone untuk memenuhi gaya hidup 
seperti chat, medsos. Sementara jutaan informasi bermanfaat untuk meningkatkan kualitas hidupnya.

Kehadiran teknologi ini tentu akan mengubah tampilan perpustakaan yang tidak sekedar kegiatan otomasi dan penyimpanan data internal. Akses informasi fisik kemungkinan besar tidak akan terjadi di perpustakaan. Perpustakaan masa depan bermetamorfosa menjadi sebuah information store berupa elektronik dan digital. Perubahan bentuk layanan juga tidak sekedar bangunan fisik, perpustakaan juga memiliki kewajiban mengedukasi masyarakat dalam menggunakan media teknologi informasi dan komunikasi secara tepat. Layanan ini dapat diwujudkan dengan melihat peran perpustakaan sebagai katalisator informasi dan laboratorium pembelajaran.

\section{Penutup}

Teknologi informasi menjadikan membanjirnya informasi, tentu semakin memanjakan pengguna. Perpustakaan sebagai pusat informasi sebagai institusi cukup merasakan dampak perkembangan teknologi. Hadirnya beragam jenis perpustakaan membuktikan evolusi layanan informasi. Dengan demikian paperless society yang telah diprediksikan oleh Lancaster saat ini semakin nyata.

Perpustakaan digital menawarkan lebih banyak kemungkinan untuk meningkatkan komunikasi secara ilmiah. Layanan komunitas ilmiah pada perpustakaan konvensional bergeser komunitas ilmiah dunia maya, yang memungkinkan membangun proyek yang terbatas geografis.

Keempat jenis perpustakaan ini memiliki nilai masing-masing. Bagi sebagian masyarakat belum dapat menerima layanan digital secara utuh. Masih ada materi perpustakaan yang belum bisa tergantikan secara elekronik. Perpustakaan hibrida menjadi penghubung layanan sesuai dengan kebutuhan pengguna. Perpustakaan hibrida menggambarkan keseimbangan dari meta informasi dan informasi cetak semakin mendekati digital. Beragamnya jenis perpustakaan bukanlah hal yang perlu diperdebatkan. Hal ini sebagai wujud perpustakaan yang senantiasa berkembang menyertai untuk memenuhi kebutuhan masyarakat, dengan tujuan utamanya: untuk mendidik dan mengilhami rasa ingin tahu intelektual masyarakat.

\section{Daftar Pustaka}

Adventures in Rhetoric: The Traditional Library. (n.d.). diunduh July 01, 2017, pada: http:// www.inthelibrarywiththeleadpipe.org/2013/ adventures-in-rhetoric/

Allen, L. (2005, April). Hybrid librarians in the 21st century library: a collaborative servi staffing model. In ACRL Twelfth National Conference, Minneapolis, Minnesota.

Atkinson, R. (1993). Networks, Hypertext, and Academic Information Services: Some LongerRange Implications. College \& Research Libraries, 54(3), 199-215. doi:10.5860/crl_54_03_199

Ashikuzzaman.(2016). Different Types of Library (Traditional, Automated, Digital, Hybrid, Virtual etc.) diunduh pada http://www.lisbdnet.com/ different-types-library-traditional-automateddigital-hybrid-virtual-etc/

Buckland, M. K. (1991). Information as thing. Journal of the American Society for Information Science (1986-1998), 42(5), 355.

Different Types of Library (Traditional, Automated, Digital, Hybrid, Virtual etc.). (2016, June 28). Pada: July 01, 2017, from http://www.lisbdnet.com/ different-types-library-traditional-automateddigital-hybrid-virtual-etc/

Bennett, S. (2005). Library as place rethinking roles, rethinking space. Washington, DC: Council on library and information resources (CLIR).

Flood, A. (2014, August 29). Bookless library opened by new US university. diunduh July 01, 2017, pada https://www.theguardian.com/ books/2014/aug/29/bookless-library-new-usuniversity-florida-polytechnic-digital

Haq, Husna (17 July 2012). "'Bookless libraries' - has it really come to this?". Christian Science Monitor 
diunduh https://www.csmonitor.com/Books/ chapter-and-verse/2012/0717/Booklesslibraries-has-it-really-come-to-this

Juchnevič, Laura .(2014). Library Roles In Changing Society. Social Transformations in Contemporary Society pada http://stics.mruni.eu/wp-content/ uploads/2014/08/STICS_2014_2_120-130.pdf

Madden, A. D. (2000, November). A definition of information. In Aslib Proceedings (Vol. 52, No. 9, pp. 343-349). MCB UP Ltd. Diunduh pada https://www.researchgate.net/ publication/241708484_A_definition_of_ information

Negi. (March, 2015). Bookless library. Diunduh Juni 30, 2017, pada: https://en.wikipedia.org/wiki/ Bookless_library

Ogunsola, L., \& A. (2011, May 1). The Next Step in Librarianship: Is the Traditional Library Dead? Library Philosophy and Practice.

Pebrianto, S. (2011). Pembangunan Sistem Informasi Perpustakaan Pada Perpustakaan Umum

Kabupaten Pacitan. Speed-Sentra Penelitian Engineering dan Edukasi, 2(2).

Reddy, R., Ager, T., Chellappa, R, Croft, W.B., DavisBrown, B., Mendel, J.M., \& Shamos,

M.I. (1999). WTEC panel report on digital information organization in Japan. Baltimore: International Technology Research Institute. Diunduh dari: http://euro.ecom.cmu.edu/people/faculty/ mshamos/1999DigitalJapan.pdf.

P. Garrod and I. Sidgreaves, Skills for New Information Professionals: The SKIP Project (Joint Information Systems Committee/Library Information Technology Centre, London, 1998)

Saleh, A. R. (2014). Pengembangan Perpustakaan Digital. Tangerang Selatan: Universitas Terbuka.

Shiri, A. (2003). Digital library research: current developments and trends. Library Review, 52(5), 198-202. doi:10.1108/00242530310476689

Sreenivasulu, V. (2000). The role of a digital librarian in the management of digital information systems (DIS). The Electronic Library, 18(1), 12-20. doi:10.1108/02640470010320380

Subrata, G., \& Kom, S. (2009). Perpustakaan Digital. Artikel Pustakawan Universitas Negeri Malang.

Sutton, S. A. (1996). Future Service Models and the Convergence of Functions:. The Reference Librarian, 25(54), 125-143. doi:10.1300/ j120v25n54_12

Wulandari, D. (2011). Mengembangkan Perpustakaan Sejalan dengan Kebutuhan Net Generation. Visi Pustaka, 13(2), 16-24. http:// repository.petra.ac.id/15260/1/net_generation1. pdf 